\title{
G15バイオミメティックな応答特性を持つ位置制御器
}

\section{Position Controllers Having Biomimetic Response Characteristics}

\author{
$\bigcirc$ 安河内哲 (九大) 正 菊植 亮 (九大) 正 山本元司 (九大)
}

Satoshi YASUKOUCHI, Kyushu University, 744 Motooka, Nishi-ku, Fukuoka

Ryo KIKUUWE, Kyushu University

Motoji YAMAMOTO, Kyushu University

Key Words: Position control, State space

\section{1 緒言}

ロボットの制御技術の発展とともに，様々な分野で新たな ロボットの活踓が期待されるようになり, パワーアシスト装 置や介護支援ロボットなどの人と接するロボットが開発され ている.人と接触するロボットにはこれまで以上の安全性が 要求されるため, 予期していない事態に陷っても異常な動作 をしない制御則が必要となる。 また，人と接触する以上，口 ボットはバイオミメティックな動きをするのが好ましい。こ の場合バイオミメティックな動きとは, 動物のように, ベル シェイプを描く滑らかな速度変化で動くことを指す。

多くのロボットは関節摩擦などモデル化の難しい要素が多 く含まれているため, 高ゲインの PID 位置制御器がよく用 いられている．高ゲインの PID 位置制御器を用いると関節 摩擦や外乱などの影響をあまり受けずに正確な位置制御が できる。しかし，入力ミスや環境の干渉などによって制御対 象の位置と目標位置の距離が大きくなると, 急加速し過大 な速度やオーバーシュートを生じることがある.そのため, 異常時の危険回避が難しく，人と接触するロボットに用いる には安全性が不十分である．また，距離が大きいときに目標 位置までの詳細な運動軌道を生成すれば滑らかな運動をさ せることはできるが，詳細な軌道生成には大きな手間がか かるため実用的ではない。

ロボットの安全な制御法の一つとして，プロクシベース ト・スライディングモード制御 (PSMC) (1) という制御則が 提案されている。この制御則は, 制御対象をプロクシと呼ば れる仮想物体を介して目標位置と接続することで, 目標位 置までの距離が大きい場合でもオーバーシュートを生じさせ ない。また，力に上限をつけた PID 制御が暗默に含まれて いるため, 力が上限に達しない限り PID 制御と同等に正確 な位置制御が行える.さらに, 既報(2)で状態空間内でのプロ クシの举動を漸化式として設計することで, 様々な応答特性 を表わすことが可能となった. 従来の $\mathrm{PSMC}^{(1)}$ では加速の滑 らかさは考慮されておらず急加速していたが，既報(2)によっ て加速を緩やかにすることができている. しかし, 最大速度 が制限されていないため, 距離が遠い場合に高速で動いて しまい危険である。

本稿では, 上述したプロクシの挙動を表わす漸化式を再 設計することで，より滑らかで安全な制御則を提案する。

\section{2 アルゴリズム}

既報 (2)で菊植が提案している制御則は下記の式 (1) で表わ される。

$$
\left.\begin{array}{rl}
p^{*}(k) & =p(k)+\frac{B(a(k-1)-a(k-2))}{T^{2} K^{*}}-\frac{L a(k-1)}{K^{*}} \\
u^{*}(k) & =U\left(p_{d}(k), q(k-1), q(k-2)\right) \\
q^{*}(k) & =q^{*}(k-1)+u^{*}(k) T \\
f^{*}(k) & =K^{*}\left(q^{*}(k)-p^{*}(k)\right) \\
f(k) & =F f^{*}(k) / \max \left(\left|f^{*}(k)\right|, F\right) \\
q(k) & =q^{*}(k)+f(k) / K^{*} \\
a(k) & =a(k-1)+T(q(k)-p(k))
\end{array}\right\}
$$

$p$ 注制御対象の位置, $p_{d}$ は目標位置, $q$ は仮想物体（プロク シ）の位置， $f$ はアクチュエータが発生する力， $K$ は比例ゲ イン, $B$ は微分ゲイン, $L$ は積分ゲイン,$H$ は時定数, $T$ は制御周期である. $p^{*}, q^{*}, f^{*}$ は計算過程で用いる中間的 な值， $a$ は制御器内部に記憶された状態変数である. 各記号 の後の $k$ は離散時間のインデックスを表わす.また, $K^{*}=$ $K+B / T+L T$ である.

$p^{*}(k)$ は制御器に与えられる入力情報とみなすことが出来 る. 制御対象に加えられる外力は, $p(k)$ を経由して $p^{*}(k) に$

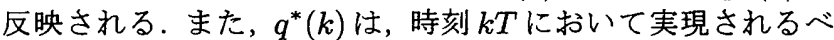
き仮想物体（プロクシ）の位置である.力 $f^{*}(k)$ は $q^{*}(k)$ を 目標位置としてPID 制御を行ったときに，アクチュエータか ら発生すべきカである.設定したアクチュエータが発生する

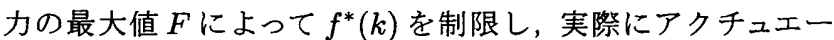
夕が発生する力 $f(k)$ とする. そして, 実際の力 $f(k)$ と矛盾 が生じないように，実際のプロクシ位置 $q(k)$ を決定する。こ の制御則は力に上限をつけた PID 制御を暗黙に含んでおり, 力が上限に達しない限り関節摩擦などの影響を受けず PID 制御と同等に正確な位置制御ができる。また，関数 $U$ はプ ロクシの挙動を決定する漸化式であり, 関数 $U$ を適切に設 計することで，様々な応答特性を表わすことができる。

\section{3 提案手法}

プロクシの位置 $q$ と速度 $u$ によって張られる状態空間を 考え, それを Fig.1のように式 (2) で表わされる6つの領域 に分割する。また，領域の境界 $\mathcal{S}$ を定義する。

$$
\begin{aligned}
\mathcal{A} & =\left\{\{q, u\} \mid q-p_{d}+H u<0 \wedge-V_{l}<u<V / 2\right\} \\
\mathcal{B} & =\left\{\{q, u\} \mid q-p_{d}+H u<0 \wedge u \geq V / 2\right\} \\
\mathcal{C} & =\left\{\{q, u\} \mid q-p_{d}+H u>0 \wedge u \geq V_{l}\right\} \\
\mathcal{D} & =\left\{\{q, u\} \mid q-p_{d}+H u>0 \wedge-V / 2<u<V_{l}\right\} \\
\mathcal{E} & =\left\{\{q, u\} \mid q-p_{d}+H u>0 \wedge u \leq-V / 2\right\} \\
\mathcal{F} & =\left\{\{q, u\} \mid q-p_{d}+H u<0 \wedge u \leq-V_{l}\right\} \\
\mathcal{S} & =\left\{\{q, u\} \mid q-p_{d}+H u=0\right\}
\end{aligned}
$$

式 (1) 中の関数 $U$ を式 (3) の $U_{\mathcal{X}}(\mathcal{X}=\mathcal{A}, \cdots, \mathcal{F}, \mathcal{S})$ で表 わす. $\mathcal{X}$ はプロクシが状態空間上のどの領域に属している かによって定まり，特にプロクシが境界 $\mathcal{S}$ を通過するとき， $\mathcal{X}=\mathcal{S}$ とする.

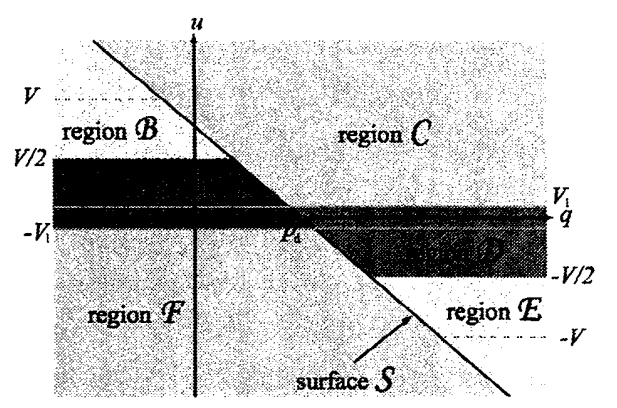

Fig.1 Regions of the controller 


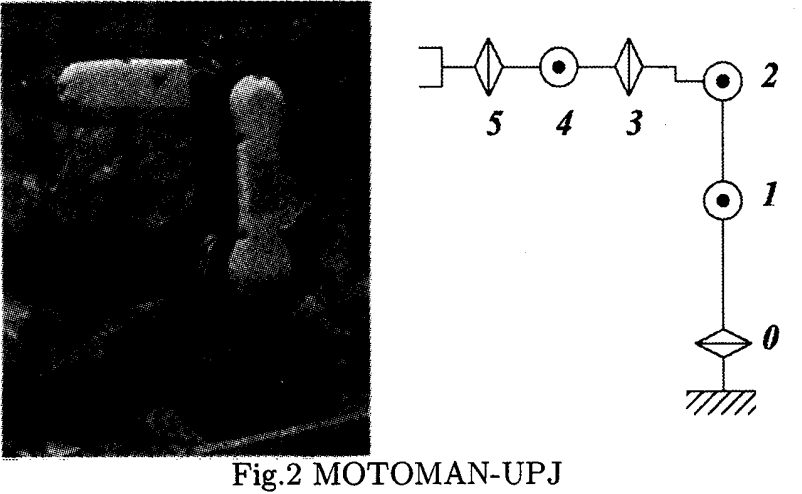

Table 1 Initial position and target position

\begin{tabular}{|c|c|c|c|c|c|c|c|}
\hline \multirow[b]{2}{*}{ symbol } & \multicolumn{6}{|c|}{ axis } & \multirow[b]{2}{*}{ unit } \\
\hline & 0 & 1 & 2 & 3 & 4 & 5 & \\
\hline$p_{0}$ & 0 & -87 & 53 & 0 & 0 & 0 & deg \\
\hline$p_{d}$ & -30 & -67 & 23 & 10 & 20 & 30 & deg \\
\hline
\end{tabular}

Table 2 Parameters for the controller

\begin{tabular}{|c|cccc|c|}
\hline \multirow{2}{*}{ symbol } & \multicolumn{4}{|c|}{ axis } & unit \\
\cline { 2 - 5 } & 0 & 1 & $\cdots$ & 5 & \\
\hline$K$ & 100 & 200 & $\cdots$ & 10 & Nm/rad \\
$B$ & 0.20 & 0.40 & $\cdots$ & 0.02 & Nms/rad \\
$L$ & 1 & 1 & $\cdots$ & 10 & Nm/(s. rad) \\
$F$ & 0.75 & 0.70 & $\cdots$ & 0.25 & $\mathrm{Nm}$ \\
$T$ & & 0.001 & & $\mathrm{~s}$ \\
$H$ & & 0.2 & & $\mathrm{~s}$ \\
$H_{a}$ & & 0.2 & & $\mathrm{~s}$ \\
$H_{d}$ & & 0.1 & & $\mathrm{~s}$ \\
$V$ & & 0.2 & & $\mathrm{rad} / \mathrm{s}$ \\
$V l$ & & 0.005 & $\mathrm{rad} / \mathrm{s}$ \\
\hline
\end{tabular}

$$
\begin{aligned}
U_{\mathcal{A}}\left(p_{d}, q, u\right) & =H_{a} \max (u, V) /\left(H_{a}-T\right) \\
U_{\mathcal{B}}\left(p_{d}, q, u\right) & =\left(H_{a} u+T V\right) /\left(H_{a}+T\right) \\
U_{\mathcal{C}}\left(p_{d}, q, u\right) & =H_{d} u /\left(H_{d}+T\right) \\
U_{\mathcal{D}}\left(p_{d}, q, u\right) & =H_{a} \min (u,-V) /\left(H_{a}-T\right) \\
U_{\mathcal{E}}\left(p_{d}, q, u\right) & =\left(H_{a} u-T V\right) /\left(H_{a}+T\right) \\
U_{\mathcal{F}}\left(p_{d}, q, u\right) & =H_{d} u /\left(H_{d}+T\right) \\
U_{\mathcal{S}}\left(p_{d}, q, u\right) & =\left(p_{d}-q\right) /(H+T)
\end{aligned}
$$

ここで, $H_{a}>0, H>H_{d}>0$ である.このときプロクシは それぞれの領域において次のような挙動を示す，領域 $\mathcal{A}$ お よびD では，指数的な速度変化で加速する． $V_{l}$ は加速の計

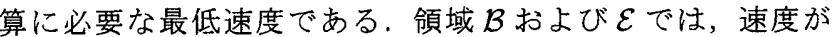
制限速度 $V$ に収束するように華減速を行う。領域 $\mathcal{C お よ ひ ゙ ~}$ $\mathcal{F}$ では，指数的に減速する．境界 $\mathcal{S}$ 近傍にあるときは，境 界に沿って動き，目標位置に収束する。

\section{4 実験}

実験には Fig.2に示す安川電機社製の 6 軸マニピュレー 夕「MOTOMAN-UPJ」を用いる.マニピュレータの 6 軸そ れぞれに対して個別に制御則を適用する，各軸の初期角度 を $p_{0}$ とし, 目標角を開始から 1 秒後までは $p_{0}, 1$ 秒後以降 は $p_{d}$ とする。. $p_{0}, p_{d}$ は Table 1 のように定める. 制御器の 各成分は Table 2 のように設定する。関節摩擦の大きさな ど軸によって特性が異なるため, 各成分の值は個別に設定す る必要がある。このときの各軸の回転角, 角速度, アクチュ エータの発生する力を測定する.

Fig.3 は実験装置をPID 制御で動かしたときの軸 0 に関 する結果である. PID 制御のゲイン $(K, B, L)$ は Table 1 の 50 分の 1 にしてある.アクチュエータが発生する力の上

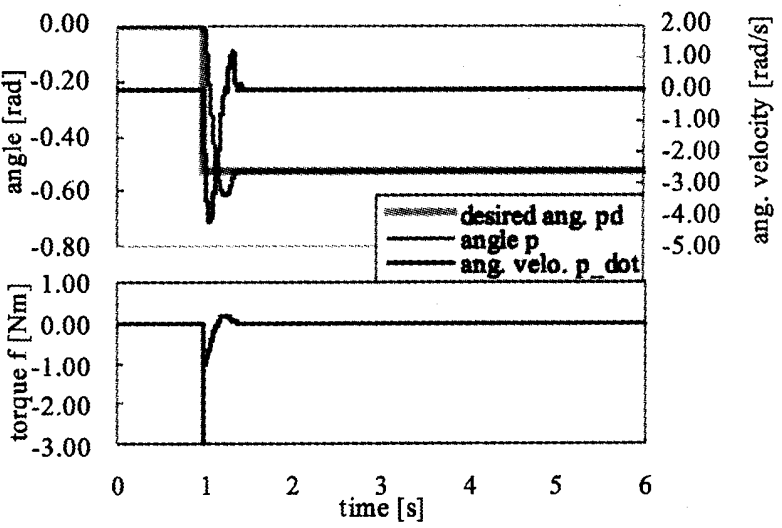

Fig.3 Results: PID control

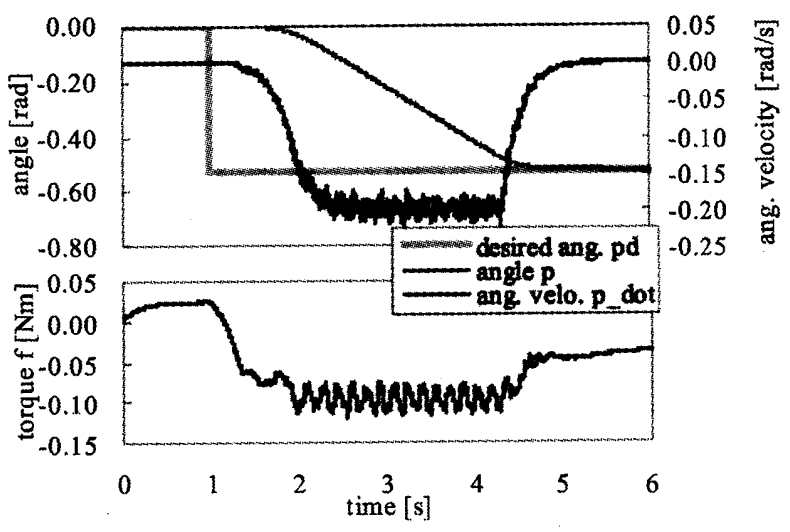

Fig.4 Results: proposed control law

限が定められていないため, 目標位置が変わったとたんに高 トルクを発生させて急加速をし，また，オーバーシュートが 生じている. 回転速度も大きくなるため, 危険性が高い.

Fig.4 は今回提案した制御則で実験したときの軸 0 に関す る結果である。角速度・発生力のスケールは Fig.3の 20 分の 1 になっている.PID 制御の時と異なり, 目標位置の急激な 変化を受けた場合でも，加速が滑らかとなっており，また， 滑らかに目標位置に収束していることがわかる，速度に制 限を付け，また，速度の変化を滑らかにしたため，PID 制御 の場合と比べると目標位置に到達するまでにかかる時間は 長くなるが，安全性は增しているといえる.

\section{5 結言}

本稿では既報(2)で菊植が提案した制御則中の関数 $U$ を適 切に再設計することで加速時の速度変化を滑らかにする方 法を提示した.

現状での問題点としては, (i) 制限速度付近で振動が発生 する, (ii) 目標位置までの距離が近い場合に滑らかな速度変 化を維持できない，(iii) 一部の速度変化が骬らかとなってい ない，ということが挙げられる。(i)の問題は PID 制御のゲ インを適切にすることで解決できると考えられる。(ii)(iii) の問題を解決するためには, より詳細に領域を分割し, 関 数 $U$ を設定する必要がある。

\section{参考文献}

(1) R. Kikuuwe and H. Fujimoto, "Proxy-based sliding mode control for accurate and safe position control", Proc. of the 2006 IEEE Int. Conf. on Robotics and Automation, (2006), pp.2631.

(2) 菊植 亮, “プロクシベースト・スライディングモード制御の再解 䣋と一般化”, 日本ロボット学会学術講演会講演論文集, $1 \mathrm{M} 15$, $(2007$ 年 9 月 $)$, 